anales de psicología, 2017, vol. $33, \mathrm{n}^{\circ} 3$ (october), 548-555 http://dx.doi.org/10.6018/analesps.33.2.264461
C) Copyright 2017: Servicio de Publicaciones de la Universidad de Murcia. Murcia (Spain) ISSN print edition: 0212-9728. ISSN web edition (http://revistas.um.es/analesps): 1695-2294

\title{
Exploring the dimensionality and the psychometric properties of the TRIM-18 in the Spanish context
}

\author{
Maria Fernández-Capo ${ }^{1 *}$, Silvia Recoder ${ }^{1}$, Juana Gómez-Benito² ${ }^{2}$ María Gámiz ${ }^{1}$, \\ Pilar Gual-García ${ }^{1}$, Patricia Díez ${ }^{1}$ and Everett Worthington, Jr. ${ }^{3}$ \\ 1 Universitat Internacional de Catalunya (Spain). \\ 2 Universidad de Barcelona (Spain). \\ 3 Virginia Commonwealth University (USA).
}

\begin{abstract}
Título: Exploración de la dimensionalidad y de las propiedades psicométricas del TRIM-18 en contexto Español.

Resumen: Introducción: La escala Transgression-Related Interpersonal Motivation. (TRIM-18) es un instrumento diseñado para evaluar perdón específico compuesto por tres subescalas: evitación, venganza y benevolencia. En el presente estudio se examina la dimensionalidad de la versión española del TRIM-18 (TRIM-18-S). Se presentan evidencias de fiabilidad y de validez de constructo de la interpretación de las puntuaciones. Método: Un total de 943 sujetos completaron el TRIM-18-S. Una submuestra de 94 participantes completaron la escala otra vez dos semanas después para el cálculo de la estabilidad temporal, y 277 participantes completaron medidas adicionales de empatía, ira e información relacionada con el tipo de ofensor para el cálculo de la validez de constructo. Resultados: El TRIM-18-S mostró buenas propiedades psicométricas. El análisis factorial confirmatorio reveló una estructura tridimensional. Los valores del alfa de Cronbach variaron entre .80 y .90. Los valores obtenidos para la fiabilidad test-retest variaron entre.74 y .84. Se hallaron evidencias de validez de constructo a partir de las correlaciones con el ítem único de medida de perdón y con empatía, ira, cercanía con el ofensor y tipo de relación. Conclusiones: La escala presenta propiedades psicométricas adecuadas para su uso en población española.
\end{abstract}

Palabras clave: perdón; episódico; escala; validación; castellano.

\section{Introduction}

Forgiveness has become a frequent topic of research in the past 20 years (McCullough, Worthington, \& Rachal, 1997). Constructed as a human strength, forgiveness has positive consequences for healthy human development (for reviews, see Toussaint, Worthington, \& Williams, 2015) and for social relationships (Tsang, McCullough, \& Fincham, 2006).

Forgiveness is distinguished from condoning, excusing, reconciling and forgetting (Baskin \& Enright, 2004). Although there is no universal definition of forgiveness, it is generally accepted that when a person forgives, his or her thoughts, feelings, and behaviors toward the offender become less negative and more positive (McCullough, Kilpatrick, Emmons, \& Larson, 2001). However, some authors (e.g., North, 1987; for a review see Worthington, 2005) highlight forgiveness as the reduction of negative responses toward the offender (i.e., anger, rumination, revenge) while others emphasize the experience of positive affect (i.e., sympathy, benevolence, love) toward the transgressor as a critical part of complete forgiveness (Enright \& Fitzgibbons, 2014; Worthington, 2006). Worthington (2005) observed that when the offenders are strangers, in poor, non-valued,

* Correspondence address [Dirección para correspondencia]:

Maria Fernández-Capo, Basic Sciences Department, Universitat Internacional de Catalunya. C/ Josep Trueta s/n, 089195 Sant Cugat del Vallès (Spain). E-mail: mariafc@,uic.es
Abstract: Introduction: The Transgression-Related Interpersonal Motivations Inventory (TRIM-18) is an instrument that assesses episodic forgiveness composed of three subscales: avoidance, revenge and benevolence. In the present study we examined the dimensionality of the Spanish version of the TRIM-18 (TRIM-18-S). We provided evidences of estimated reliability and construct validity of the interpretation of the scores. Method: A total of 943 participants completed the TRIM-18-S. A subset of 94 participants completed the measure again to allow computation of two-week estimated temporal stability, and 277 participants completed additional measures of empathy, anger, and information regarding the relation with the offender to allow computations supporting construct validity. Results: The TRIM-18-S showed good psychometric properties. Confirmatory factor analysis revealed a three-factor structure. Alphas ranged from .80 to .90 Two week estimated test-retest correlations ranged from .74 to .84. Construct validity was supported by correlations with a single-item measuring forgiveness and with empathy, state anger, and closeness and type of relationship. Conclusions: The scale presents adequate psychometric properties for its potential use in Spanish population.

Keywords: forgiveness; episodic; scale; validation; Spanish. or non-continuing relationships, the focus is on reducing negative emotions and motives. However, when people are in valued, continuing relationships, the focus is on both reducing the negative and then increasing the positive.

Forgiveness is sometimes complex and especially difficult when harm is severe (Karremans, Van Lange, \& Holland, 2005) and offenders are unrepentant (Bono, McCullough, \& Root, 2008). Worthington (2006) distinguished two basic types of transgressions: hurts and offenses. The first violate people's physical or psychological boundaries. Offenses or "wrongs" violate moral boundaries. Forgiveness is usually correlated with higher empathy and lower anger states (Fehr, Gelfand, \& Nag, 2010; McCullough et al., 1997). Also, McCullough et al. (1998) suggested that relationship closeness might facilitate forgiveness. Thus, multiple characteristics of the forgiver, the transgressor, the relationship and the offense affect whether forgiveness is experienced (for a review, see Fehr et al., 2010). Considering the different conceptualizations and the high interest in forgiveness, diverse measures have been developed to assess several types and aspects of forgiveness (for a review, see Worthington, et al., 2015). According to Worthington et al. (2015), the specificity with which forgiveness is assessed includes dispositional (i.e., stable personality trait), episodic (i.e., linked to a particular offense), and dyadic (i.e., unique offenses that occur within that relationship) forgiveness.

Within episodic forgiveness, some scales focus on the negative dimension, that means reduction of anger, venge- 
ance, etc., (e.g., Marital Offense Specific Forgiveness Scale; Paleari, Regalia, \& Fincham, 2009); while others also consider positive dimensions of forgiveness as benevolence (e.g., Rye Forgiveness Scale; Rye, Loiacono, Folck, Olszewski, Heim, \& Madia, 2001). The Transgression-Related Interpersonal Motivations Inventory (TRIM) is the most used instrument (Worthington et al., 2015). The first version (TRIM-12) was developed by McCullough et al. (1998). It assesses revenge (5 items) and avoidance ( 7 items) motivations following a perceived interpersonal offense by a particular person. These subscales measure two negative dimensions of forgiveness. Afterwards, six items were added, making the TRIM-18 (McCullough \& Hoyt, 2002; McCullough, Root, \& Cohen, 2006). The new items assessed benevolence, one of the positive dimensions of forgiveness. The authors proposed a tridimensional structure for TRIM-18; however exploratory factor analyses revealed a two factor solution; the revenge factor, composed by the same 5 items of the TRIM-12, and another factor called avoidance versus benevolence, composed by the remaining 13 items. Subsequent Rasch analyses had shown that the TRIM-18 can be portrayed as having one dimension (i.e., forgiveness, with revenge and avoidance items being reverse scored; McCullough, Luna, Berry, Tabak, \& Bono, 2010). Which structure is apparent in factor analytic solutions likely depends on the nature of the relationships being considered in the particular samples analyzed. For example, people in close marriages likely show little revenge motivation. People offended by crimes or former spouses with whom they no longer interact likely show little motivation towards benevolence.

When trying to translate the TRIM-18 into Chinese and evaluate the psychometric support for it, Wong, Chu, and Chan (2013) used exploratory factor analysis (EFA) and obtained a two-factor solution. The first factor appeared to be a unidimensional scale composed of the avoidance and revenge items (i.e., unforgiveness); whereas the second factor comprised the remaining 6 items of benevolence. Because the inclusion of the benevolence construct within the definition of forgiveness was taken to be debatable, Wong et al. decided to keep only the first factor in the final scale, called Chinese-TRIM (C-TRIM). They treated the second factor as an independent scale to assess benevolence motivations.

Also, there has been a previous published validation of TRIM-18 in a Chilean sample (Guzmán, Tapia, Tejada, \& Valenzuela, 2014). The authors translated the TRIM-18 into Spanish and presented results showing acceptable estimated internal consistency and a good fit of the data to a tridimensional factorial structure. However it was adapted for specific use within couples. The final version of the instrument included only 15 items from the 18 of the original Englishversion scale. First, they did not include item 15 "I cut off the relationship with him/her" because it was not clear its applicability in ongoing relationships. Second, they removed item 3 "Even though his/her actions hurt me, I have goodwill for him/ her" because it cross-loaded on both revenge and benevolence subscales. Finally, they excluded item 1 "I'll make him/her pay" because it loaded on the avoidance factor instead of on its original factor, revenge, which for committed couples seems logically consistent. Whereas the Chilean version had adequate psychometric support within its intended use with couples, there is a need for a Spanish-language version that is more broadly applicable.

Although none of the previous studies supported the tridimensional structure of the TRIM-18 (including all the items), nowadays the TRIM-18 is often used and interpreted considering each of the three subscales separately. Thus, the objective of the present study is to explore the dimensionality of the 18-item Spanish version of TRIM-18 (TRIM-18-S). We hope to provide psychometric evidence related to the estimated reliability of scores and to offer evidence of the (construct) validity of interpreting the scores as assessing the construct of forgiveness. Specifically, we aimed to test the three different models proposed in previous studies (unidimensional, bi-dimensional or tri-dimensional) to figure out which one defines better the dimensionality of the TRIM-18 in the Spanish population without restricting the relationship in which the transgression occurred. We also examined the internal structure and the estimated temporal stability of the scale and provided evidence of construct validity by studying the relationship of TRIM-18-S scores (and subscale scores) with a single-item rating of forgiveness and with other related constructs like empathy, state anger, closeness of the actual relationship, and type of offender.

Some existing instruments measure forgiveness within Spanish population. However they were focused on divorced people (CPD-S; Yárnoz-Yaben \& Comino, 2012), or they measure dispositional forgiveness (CAPER; Casullo \& Fernandez-Liporace, 2005). Thus, instruments assessing episodic forgiveness within the Spanish context are still lacking. Because forgiveness is a topic of increasing interest, and the design of interventions to promote forgiveness is becoming popular (see Wade, Hoyt, Kidwell, \& Worthington, 2014, for a meta-analysis of interventions), a psychometrically sound measure that is generally available regardless of type of relationship will allow both researchers and clinical professionals to study forgiveness in the Spanish population.

\section{Method}

\section{Participants}

943 participants completed the TRIM-18-S (34.9\% males and $65.1 \%$ females), ranging in age from 18 to $73(M=$ $30.86, S D=12.94)$. The inclusion criteria were that participants must be both Spanish and 18 years old or over. To avoid burdening participants, we selected subsamples based on power analyses to complete additional measures. Of these 943 participants, 300 were selected at random, and 277 of those $\left(33.9 \%\right.$ males and $66.1 \%$ females; $M_{\text {age }}=32.69$, SD $=13.28)$ completed additional measures to provide evidence pertinent to the validity of interpreting scores. We selected 
at random 100 other participants and of those, 94 (31.5\% males and $64.9 \%$ females; $\left.M_{\text {age }}=27.11, S D=10.00\right)$ completed the TRIM-18-S to assess estimated two-week testretest reliability.

\section{Instruments}

Transgression-Related Interpersonal Motivations Inventory (TRIM-18; McCullough et al., 2006). The TRIM-18 consists of 18 items that measure avoidance, revenge and benevolence motivations toward a particular offender for a particular offense (i.e., episodic forgiveness). Participants are instructed to think about a hurtful transgression and then indicate their agreement with each item using a 5-point response option ranging from 1 (strongly disagree) to 5 (strongly agree). Higher scores indicate higher motivations.

Spanish version of the State-Trait Anger Expression Inventory-2 (STAXI-2; psychometric data provided by Miguel-Tobal, Casado, Cano-Vindel, \& Spielberger, 2001). This self-report instrument evaluates the general disposition to feel and express anger. The Spanish version consists of 49 items and 6 subscales, measured using 4-point response options $(1=$ not at all to $4=$ very much so). For the present study, we used the state anger subscale (15 items; e.g., "I am furious"). The STAXI-2 is a psychometrically well-supported angerassessment instrument that has good psychometric properties in adults without psychological disorders (alphas ranging from .69 to .89 ).

Test de Empatia Cognitiva y Afectiva (TECA; López-Pérez, Fernández-Pinto, \& Abad, 2008). Served as a self-report measure, it suggests an overall assessment of cognitive and affective empathy (e.g., "Me siento bien si los demás se divierten") through four scales: perspective adoption, emotional understanding, empathic stress and empathic joy. The scale also permits one to obtain a total score. This instrument consists of 33 items (scores range from 33 to 165), which are answered according to a 5 -point response option where $1=I$ totally disagree, and $5=I$ totally agree. Scores on the TECA had a Cronbach's alpha of 86.

Single item of forgiveness: Participants answered a single-item measure (used by McCullough et al., 1998) to indicate the extent to which they had forgiven their offender. The 6point response option ranged from $0=$ none to $5=$ completely.

Closeness of actual relationship: Actual relational closeness was assessed answering "On a scale from 1 to 5, please indicate how close you are right now to the person who hurt you?" ( 1 = no at all to 5 = extremely close; Tsang et al., 2006).

Offender type: Through the reported offense of the participants, we categorized the type of offender taking into account if the relationship was valued (e.g., family member, friend, partner) or non-valued (e.g. employees, workmates, neighbor).

\section{Procedure}

After obtaining the permission from the author of the English version of the TRIM, the Spanish translation of the TRIM-18 was done by two bilingual licensed psychologists whose first language was Spanish and second English. After this, two bilingual licensed psychologists (first language English and second Spanish) independently did the backtranslation into English. Then, the possible discrepancies between the new version and the original were solved by consensus. By the time we started the study we were not aware of the Chilean version of the TRIM. However, when we discovered that version we analyzed their similarities and differences. Because our version was similar to the Chilean one except for the verb tense in items 6,14, and 16 (e.g., he dejado vs $d e j o$ ), we ran a pilot study as suggested by Muñiz, Elosua, and Hambleton (2013) to test which formulation of the items was more understandable. Ten pilot study participants indicated which items they comprehended better. The Chilean items were slightly preferred; thus, we used them. In addition, we added the three items removed by Guzmán et al. (2014) to extend the use of the questionnaire to contexts beyond the couples.

The sample was recruited using snowball-sampling technique. Participation was voluntary and anonymous. Participants accessed the questionnaires online. After giving their informed consent and supplying demographic information, participants were instructed to recall a specific offense, write it down, and complete the TRIM-18-S regarding that offense. The 100 randomly chosen participants were recontacted two weeks later to complete the TRIM-18-S a second time. 94 responses were obtained and used to estimate twoweek test-retest reliability. Participation lasted 10 minutes.

Participants $(N=300)$ selected to evaluate evidence supporting construct validity received an envelope with the TRIM-18-S and the measures presented in the instruments section. Of those selected, 277 participated. To avoid biases caused by the influence of the other measures (e.g., empathy), the TRIM was always presented first. The protocol took around 20 minutes.

\section{Data Analysis}

Data was cleaned and study measures were created using IBM Statistics SPSS - Version 22 (IBM Corp., 2013). The data was checked for lack of normality, lack of linearity, and heteroscedasticity through the examination of basic statistics and histograms. We found no outliers, nor were there any missing values. Univariate and multivariate kurtosis were found, thus we applied the Satorra-Bentler scaled maximum likelihood (ML) correction (Satorra \& Bentler, 1988) to adjust the model Chi-square. For the analysis of the dimensionality of TRIM-18-S, Mplus version 6 (Muthén \& Muthén, 1998-2011) was used to perform a confirmatory factor analysis (CFA). Given the sensitivity of the Chi-square statistic to sample size, model fit was evaluated also based on the 
comparative fit index (CFI), root mean square error of approximation (RMSEA), standardized root mean square residual (SRMR), and evaluation of parameter estimates (Hoyle \& Panter, 1995). CFI values above 90 indicate good fit. RMSEA values below .08 indicated a reasonable fit; whereas values below .05 are considered a good fit. SRMR values are expected to be below .06 ( $\mathrm{Hu} \&$ Bentler, 1999). The Chi-square values for Satorra-Bentler scaled ML cannot be used for Chi-square difference testing directly, thus, we computed the adjusted Chi-square difference (Statmodel.com, 2016) to make comparison between models. To explore the psychometric properties of the TRIM-18-S different indicators were computed. Intraclass correlation coefficient (ICC) is a measure of agreement and was calculated for estimated test-retest reliability analysis, following recommendations by González, Villegas, Atucha, and Fajardo (2014). Also, Cronbach's alpha was used to estimate internal consistency of scores. Pearson correlation coefficient was used to assess the relationship between the TRIM-18-S and empathy, state anger and single item of forgiveness. Closeness of the actual relationship was treated as an ordinal variable and thus we used Spearman correlation to assess the relationship of this variable with the TRIM-18-S scores. An independent samples $t$-test with benevolence as dependent variable and type of the offender as independent variable was used to analyze the data. Finally, to test whether the TRIM-18-S improved the assessment of forgiveness in comparison to TRIM-12 and to TRIM-15 (Chilean version) we conducted two hierarchical regression analyses. All these analysis, together with descriptive information, were performed using the SPSS statistical package.

\section{Results}

\section{Factor Structure}

After verifying the sample adequacy to conduct factor analysis $\left(\mathrm{KMO}=.951\right.$; Barlett: $\chi^{2}=11042.001$;f $=153$; $<.001)$, we conducted confirmatory factor analysis to test the different models. In Table 1, we present the results for all models-uni-dimensional, bi-dimensional, and tridimensional and a second order model. We found an inadequate fit of model to the data for the unidimensional (Model 1) and for the two-factor model (Model 2) as indicated by too-small (i.e., less than .90) CFI values $(\mathrm{CFI}=.81 / .89)$, and too high (more than .08) RMSEA values (RMSEA = $.12 / .09)$, respectively. In contrast, the model fit was considerably improved when fitting the three-factor model (Model 3 ), $\mathrm{CFI}=.93$, RMSEA $=.07$, and SRMR $=.06$. Although the Chi-square value was significant, it is usually due to high sensitivity of Chi-square value to N. The CFI, RMSEA, and SRMR were all acceptable. The tri-dimensional model fit was good.

Table 1. Summary of model fit information for all models tested.

\begin{tabular}{cccccc}
\hline Model & $\chi^{\mathbf{2}}(\mathbf{d f})$ & CFI & TLI & RMSEA (90\%C.I.) & SRMR \\
\hline Model 1 (1-factor) & $1869.570(135)^{* * *}$ & .805 & .779 & $.117(.112-.121)$ & .092 \\
Model 2 (2-factor) & $1157.860(134)^{* * *}$ & .885 & .869 & $.090(.085-.095)$ & .064 \\
Model 3 (3-factor) & $655.117(132)^{* * *}$ & .941 & .932 & $.065(.060-.070)$ & .058 \\
Model 4 (2 $2^{\circ}$ order) & $655.117(132)^{* * *}$ & .938 & .928 & $.065(.060-.070)$ & .058 \\
\hline
\end{tabular}

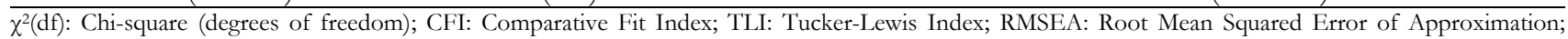
SRMR: Standardized Root Mean squared Residual. $* * * p<.001$.

When comparing the different models (see Table 2) significant differences were obtained for the adjusted Chi square differences and the increments in the CFI and TLI were higher than .05 in all cases, indicating that the Model 3 is the one that best fits the data.

Table 2. Comparison of the different models of the TRIM-18-S.

\begin{tabular}{ccccc}
\hline Models compared & $\begin{array}{c}\text { Adjusted } \chi^{2} \\
\text { Difference Test }\end{array}$ & $\boldsymbol{\Delta} \mathbf{d f}$ & $\boldsymbol{\Delta} \mathbf{C F I}$ & $\boldsymbol{\Delta} \mathbf{T L I}$ \\
\hline 1-factor against 2-factor & $259.863^{* * *}$ & 1 & .080 & .090 \\
1-factor against 3-factor & $218.972^{* * *}$ & 3 & .136 & .153 \\
2-factor against 3-factor & $178.206^{* * *}$ & 2 & .056 & .063 \\
\hline
\end{tabular}

In Table 3, we show the standardized factor loadings, all of them significant, and between moderate and high strength for items $2,5,7,10,11,15$, and 18 on avoidance, for items
$1,4,9,13$, and 17 on revenge, and for items $3,6,8,12,14$, and 16 on benevolence. The correlations of avoidance with revenge and benevolence factors were $r=.52, p<.001$; and $r=-.85, p<.001$ respectively, and the correlation between revenge and benevolence factors was $r=-.51, p<.001$. Because the TRIM-18 is a measure of forgiveness, obtaining a total score instead of three different punctuations may be interesting. Thus, we tested a second-order model (Model 4) defining a general factor of forgiveness formed by the three subscales: avoidance, revenge, and benevolence. The Model 4 was equivalent to Model $3\left(\chi^{2}\right.$ Model3-Model $\left.4=.000\right)$ (because of the same number of degrees of freedom and so the number of parameters) but instead of obtaining correlations among factors, these were replaced by factor loadings (Table 3). 
Table 3. TRIM-18-S items and their confirmatory factor loadings for the second-order model.

\begin{tabular}{|c|c|c|c|c|}
\hline \multirow[b]{2}{*}{ Items } & \multicolumn{4}{|c|}{ Standardized Factor Loadings } \\
\hline & Avoidance & Revenge & Benevolence & Forgiveness \\
\hline 2. Mantengo entre nosotros/as la mayor distancia posible & .82 & & & \\
\hline 5. Vivo como si él/ ella no existiera, como si no estuviera cerca & .76 & & & \\
\hline 7. No confío en él/ ella & .70 & & & \\
\hline 10. Me cuesta ser cariñoso / a con él/ ella & .69 & & & \\
\hline 11. Le / a evito & .82 & & & \\
\hline 15. Corto la relación con él/ ella & .88 & & & \\
\hline 18. Me alejo de él/ ella & .88 & & & \\
\hline 1. Hago que pague por lo que bizo & & .57 & & \\
\hline 4. Deseo que le suceda algo malo & & .74 & & \\
\hline 9. Deseo que él/ ella obtenga su merecido & & .72 & & \\
\hline 13. Planeo vengarme & & .67 & & \\
\hline 17. Quiero verle/ a sufrir y en estado de miseria & & .72 & & \\
\hline 3. A pesar de que sus acciones me han herido, igualmente le deseo lo mejor & & & .56 & \\
\hline 6. He dejado de lado el rencor para que retomemos nuestra relación & & & .84 & \\
\hline 8. A pesar de lo que me bizo, deseo que volvamos a tener una buena relación & & & .85 & \\
\hline 12. A pesar de que me bizo daño, he dejado el dolor de lado para retomar nuestra relación & & & .90 & \\
\hline 14. He dejado atrás el dolor y el resentimiento & & & .47 & \\
\hline 16. He dejado atrás la rabia para trabajar en intentar rehacer nuestra relación & & & .85 & \\
\hline \multicolumn{5}{|l|}{ Factors } \\
\hline Avoidance (Evitación) & & & & -.93 \\
\hline Revenge (Vengan₹a) & & & & -.56 \\
\hline Benevolence (Benevolencia) & & & & .92 \\
\hline
\end{tabular}

Because Model 4 presented adequate fit it was possible to establish a total score of forgiveness. To do so, we reverse coded the items of both the avoidance and revenge subscales and then summed the direct scores of each of the subscales. A Total Forgiveness score (TF) was obtained, in which higher scores indicated higher forgiveness.

\section{Estimated Reliabilities of Scores}

Estimated internal consistency was computed using Cronbach's alpha coefficients. Alphas were .90 for avoidance, .80 for revenge, .89 for benevolence, and .94 for TF. We also assessed 2-week estimated test-retest reliability using the intraclass correlation coefficient (ICC). ICCs for each subscale were .71 for avoidance, .81 for revenge, .74 for benevolence, and .81 for TF.

\section{Sex Differences}

Sex differences were found for revenge motivations, but not for avoidance, benevolence or total forgiveness. Males scored significantly higher on revenge $\left(M_{\text {male }}=8.89, S D_{\text {male }}=\right.$ $3.90)$ than females $\left(M_{\text {female }}=7.90, S D_{\text {female }}=3.40\right), t(1,928)=$ $3.87, p<.001$. In addition, females rated significantly higher on empathy $\left(M_{\text {female }}=123.63, S D_{\text {female }}=13.21\right)$ than males $\left(M_{\text {male }}=117.41, S D_{\text {male }}=14.54\right), t(1,261)=3.47, p=.001$.

\section{Associations between TRIM-18-S and Related Vari-} ables

The TRIM-18-S subscales correlated in the predicted direction with all the measures. Because the variables compris- ing revenge, the single item measuring forgiveness, and the STAXI did not distribute normally, we used Spearman correlations (recommended for non-normal distributions) in the analyses that include those variables. As expected, the single item measuring forgiveness was negatively correlated with avoidance $(r=-.57, p<.001)$, revenge $(r=-.54, p<.001)$, and positively correlated with benevolence $(r=.63, p<$ $.001)$, and TF ( $r=.63, p<.001)$. TECA (i.e., empathy) was negatively correlated with avoidance $(r=-.15, p=.018)$, and revenge $(r=-.21, p=.001)$, and positively correlated with benevolence $(r=.19, p=.002)$, and TF $(r=.19, p=.002)$. Finally, state anger was positively correlated with revenge $(r$ $=.21, \mathrm{p}=.003$ ) but not with the remaining subscales. Spearman correlation was also used to assess the relation between the TRIM-18-S scores and the closeness of actual relationship. Close relationships were negatively correlated with avoidance $(r=-.63, p<.001)$, revenge $(r=-.35, p<$ $.001)$, and positively correlated with benevolence $(r=.54, p$ $<.001)$ and TF $(r=.62, p<.001)$. To test whether benevolence differed depending on the type of offender (i.e., valued versus non-valued person) in those participants with low scores on unforgiveness, we conducted an independent samples $t$-test. We computed a global unforgiveness score by summing avoidance and revenge subscales and selected those with scores below 241. There was a significant difference in benevolence scores between positively valued relationship $(M=25.37, S D=4.22)$ and non-valued relationships $(M=22.48, S D=5.97)$ conditions; $t(1,181)=3.21, p$ $=.015$, indicating that people offended by a valued person

${ }^{1}$ Scores reflecting disagreement range from 7 to 14 in the avoidance subscale and from 5 to 10 in the revenge subscale. Thus, scores ranging from 12 to 24 reflect low unforgiveness. 
are more benevolent than those offended in a non-valued relationship.

To test whether TRIM-18-S improved the assessment of forgiveness in comparison to TRIM-12, we conducted a hierarchical regression (see Table 4) with the single item measuring forgiveness as criterion variable and including avoidance and revenge in a first step, and benevolence in a second step. The effects of avoidance and revenge accounted for the $40 \%$ of the variance $\left(R^{2}=.40, p<.001\right)$, and the benevolence subscale accounted for an additional 10\% $\left(\Delta R^{2}\right.$ $=.10, p<.001)$. Both models were significant although the second showed a significantly higher predictive capability.

We conducted another hierarchical regression (Table 4) to see whether TRIM-18-S improved the assessment of forgiveness with respect to the Chilean TRIM-15. The single item measuring forgiveness was the criterion variable, TRIM-15 was entered in Step 1, and the remaining three items were entered in Step 2. The effects of the TRIM-15 accounted for the $47 \%$ of the variance $\left(R^{2}=.47, p<.001\right)$, but the remaining three items accounted for an additional $3 \%\left(\Delta \mathrm{R}^{2}=.03, p=.01\right)$. Again, both models were significant but the second showed significantly higher predictive capability.

Table 4. Results of Hierarchical Regression Analyses predicting Forgiveness.

\begin{tabular}{|c|c|c|c|c|c|c|}
\hline Step & Variables & B & SE & $\beta$ & $t$ & $\Delta \mathbf{R}^{2}$ \\
\hline \multicolumn{7}{|c|}{ Single item of forgiveness on avoidance, revenge and benevolence } \\
\hline \multirow[t]{3}{*}{1} & (Constant) & 5.85 & .19 & & $31.10^{*}$ & $.40^{*}$ \\
\hline & Avoidance & -.06 & .01 & -.42 & $-5.98^{*}$ & \\
\hline & Revenge & -.11 & .03 & -.29 & $-4.16^{*}$ & \\
\hline \multirow[t]{4}{*}{2} & (Constant) & 2.30 & .63 & & $3.67 *$ & $.10^{*}$ \\
\hline & Avoidance & .01 & .01 & .01 & .09 & \\
\hline & Revenge & -.09 & .02 & -.25 & $-3.78^{*}$ & \\
\hline & Benevolence & .11 & .02 & .56 & $5.92 *$ & \\
\hline \multicolumn{7}{|c|}{ Single item of forgiveness on TRIM-15 and TRIM-18 } \\
\hline \multirow[t]{4}{*}{1} & (Constant) & 2.94 & .56 & & $5.23^{*}$ & $.47^{*}$ \\
\hline & Avoidance & -.01 & .02 & -.06 & -.63 & \\
\hline & Revenge & -.11 & .03 & -.23 & $-4.09 *$ & \\
\hline & Benevolence & .10 & .02 & .49 & $5.47^{*}$ & \\
\hline \multirow[t]{7}{*}{2} & (Constant) & 2.05 & .65 & & $3.14 *$ & $.03^{*}$ \\
\hline & Avoidance & -.00 & .02 & -.02 & -.14 & \\
\hline & Revenge & -.06 & .03 & -.13 & -1.83 & \\
\hline & Benevolence & .10 & .02 & .45 & $4.62 *$ & \\
\hline & Item 1 & -.13 & .07 & -.12 & -1.84 & \\
\hline & Item 3 & .19 & .07 & .20 & $2.80^{*}$ & \\
\hline & Item 15 & -.02 & .09 & -.02 & -.20 & \\
\hline
\end{tabular}

Note. ${ }^{*} p<.05$.

\section{Discussion}

The main objectives of this study were two. First, to explore the dimensionality of the TRIM-18- $\mathrm{S}$ by testing the different models of forgiveness proposed in previous studies. Second, to provide evidence of estimated reliability of the scores, and support for validity of interpreting the TRIM-18$\mathrm{S}$ scale to assess revenge, avoidance, and benevolence after a transgression (i.e., construct validity). Besides, a further ob- jective was to measure whether the TRIM-18-S was better assessing forgiveness than TRIM-12 (in Spanish) and the Chilean version (TRIM-15).

Our results obtained in the CFA analyses supported the interpretation that the TRIM-18-S has a three-factor structure in accordance with the original structure proposed by McCullough and Hoyt (2002). The Chi-square value obtained for the most saturated model differed significantly from the Chi-square values of Models 1 and 2, suggesting that the fit to the data of the other solutions could be considered less optimal. We explored the possibility of a second-order factor of forgiveness representing those motivations as an overall forgiveness. Model 4 did not explain the structure of the TRIM-18-S any better than Model 3; fit indices were comparable. Model 3 was simpler in structure, but the second order solution of Model 4 permitted computation of a total forgiveness score in addition to the three factors. We also found sex differences in revenge, suggesting that the three factors do not behave completely as a simple unidimensional scale. Model 4, nevertheless, can be interpreted to fit generally with the proposal of McCullough et al. (2010). They posit (and demonstrate using item analysis) that the TRIM-18-S can be interpreted to measure a unidimensional factor of forgiveness. We were able to add a secondorder factor that allows obtaining a Total Forgiveness score. Large factor loadings indicating strong relationships between the items and the first-order factors with their respective underlying latent factor were obtained, thus supporting content validity of the TRIM-18-S (Rios \& Wells, 2014). Therefore, our findings suggest, practically speaking, that the Spanish version can support either a single-dimension or three-dimension interpretation, depending on the hypotheses and proposed use by investigators.

The estimated internal consistency of the scores on the TRIM-18-S is very close to the original version $(\alpha \mathrm{s} \geq .85$; McCullough \& Hoyt, 2002), and we obtained generally stronger alphas than the Chilean study (whose $\alpha$ s ranged from .67-.94). Alpha values were all larger than .80 in the TRIM-18-S, suggesting sufficient estimated reliability for use in social, personality, and health research. Our findings with the TRIM-18-S are consistent with the evaluation of Worthington et al. (2015) who evaluated English versions of all forgiveness measures. Also, all intraclass correlation coefficients obtained were above .71, supporting evidence of strong test-retest stability over a two-week period.

High and significant correlations (above .53) among the TRIM-18-S and the single item measuring forgiveness indicate sufficient criterion validity (Muñiz, Hidalgo, GarciaCueto, Martínez, \& Moreno, 2005). Also, meaningful associations were found between the TRIM-18-S scores and closeness of actual relationship. The more positive and close the relationship was, the more one forgives (McCullough et al., 1998). Significant correlations were found between empathy and TRIM-18-S (McCullough et al., 1997) even though they were lower than expected. Finally, state anger correlated with the revenge subscale (Allred, 1999). All these 
results are good indicators of construct validity. Moreover, the TRIM-18-S helps investigators understand how individuals forgive depending on the role of the offender as a nonvalued or positively-valued person (Worthington, 2005). Although the inclusion of a benevolent dimension within the construct of forgiveness is still debatable by a few investigators (Wong et al., 2013; cf. Worthington, 2005), we obtained significantly higher scores on benevolence for the forgivers with valued relationships (versus non-valued relationships). This is in line with Worthington's (2005) observation stating that when the offenders are strangers or people in nonvalued relationships, the focus is on reducing the negative while in valued relationships, the focus is on both reducing the negative and increasing the positive.

TRIM-18-S improves the assessment of forgiveness in comparison to TRIM-12 (in Spanish). The results obtained in our regression analysis showed that the benevolence dimension has incremental effects on predicting forgiveness (i.e., incremental validity). The addition of the benevolence subscale into the instrument permits going further in the assessment of forgiveness. The TRIM-18-S allows assessing both the reduction of unforgiveness (i.e., avoidance and revenge) and the increase of forgiveness (i.e., benevolence). Because the positive dimension of benevolence in forgiveness plays an important role, at least in close relationships, having a psychometrically well-supported instrument will facilitate the evaluation of interventions in forgiveness.

When compared to the Chilean version (TRIM-15), the regression results indicated that the prediction of forgiveness significantly improved when the three remaining items were added. The TRIM-18-S retains all the original items and can be used in all types of relationships and for cross-cultural studies. In addition, it permits investigators to obtain a total score; this would significantly simplify the evaluation of forgiveness interventions.

\section{References}

Allred, K.G. (1999). Anger and retaliation: Toward an understanding of impassioned conflict in organizations. In R. J. Bies, R. J. Lewicki, \& B. H. Sheppard (Eds.), Research on negotiation in organization (Vol. 7, pp.27-58). Greenwich, CT: JAI Press.

Baskin, T. W., \& Enright, R. D. (2004). Intervention studies on forgiveness: A meta-analysis. Journal of Counseling and Development: JCD, 82(1), 79. doi: 10.1002/j.1556-6678.2004.tb00288.x

Bono, G., McCullough, M. E., \& Root, L. M. (2008). Forgiveness, feeling connected to others, and well-being: Two longitudinal studies. Personality and Social Psychology Bulletin, 34(2), 182-195. doi: $10.1177 / 0146167207310025$

Casullo, M. M., \& Fernandez-Liporace, M. (2005). Evaluación de la capacidad de perdonar. Desarrollo y validación de una escala. Acta Psiquiátrica y Psicológica de América latina, 51(1), 14-20.

Enright, R. D., \& Fitzgibbons, R. (2014). Forgiveness therapy: An empirical guide for resolving anger and restoring hope. Washington, D. C.: American Psychological Association. doi: 10.1037/14526-000

Fehr, R., Gelfand, M.J., \& Nag, M. (2010). The road to forgiveness: a metaanalytic synthesis of its situational and dispositional correlates. Psychological Bulletin, 136, 894-914. doi: 10.2139/a1612494

González, M. Á. M., Villegas, A. S., Atucha, E. T., \& Fajardo, F. J. F. (2014). Bioestadística amigable. Madrid: Elsevier España.

\section{Limitations and Future Directions}

Although the present work demonstrates that the TRIM18-S has good psychometric properties for its use within a general Spanish population, the sampling method (i.e., snowball sampling) was not optimal. This sampling method did not provide a probabilistic sample allowing easy generalization of results to a sample. We attempted to draw as large a sample as possible to ensure the best sampling we could achieve with the snowball method. However, we urge users of TRIM-18-S to do so with circumspection. Future research should test the dimensionality of the TRIM-18-S in other type of groups like clinical samples, satisfied and troubled couples, and situations involving crimes or abuse. Additionally, although the TRIM-18-S correlated in the expected direction with empathy, state anger, and closeness of the actual relationship, future studies should more deeply explore its association with other external variables-like gold standards of behavior like reconciliation or divorce after an affair-to provide more evidence of convergent and discriminant validity, respectively. The TRIM-18-S includes the same 18 items as did the original scale in English, allowing the instrument to be involved in comparisons across different populations. However, cross-cultural testing for measurement invariance needs to be done.

In conclusion, the present study reported data supporting the conclusion that the TRIM-18-S is a psychometrically well-supported scale with evidence both for estimated reliability (internal and test-retest) and for supporting construct validity in interpreting the scores for the evaluation of episodic forgiveness in general population. It is hoped that this instrument will be used in the Spanish context as a basis for further studies of forgiveness with the aim of developing specialized intervention strategies that help people to forgive.

Guzmán, M., Tapia, M. J., Tejada, M., \& Valenzuela, K. (2014). Assessment of forgiveness in intimate relationships: Psychometric properties of the Transgression-related Interpersonal Motivations Inventory (TRIM-18) in a Chilean context]. Psykhe, 23(2), 1-12. doi: 10.7764/psykhe.23.2.623

Hoyle, R. H., \& Panter, A. T. (1995). Writing about structural equation models. In R. H. Hoyle, Structural equation modeling: concepts, issues, and applications. Newbury Park, CA: Sage.

Hu, L. T., \& Bentler, P. M. (1999). Cutoff criteria for fit indexes in covariance structure analysis: Conventional criteria versus new alternatives. Structural Equation Modeling: A Multidisciplinary Journal, 6(1), 1-55. doi:10.1080/10705519909540118

Karremans, J. C., Van Lange, P. A., \& Holland, R. W. (2005). Forgiveness and its associations with prosocial thinking, feeling, and doing beyond the relationship with the offender. Personality and Social Psychology Bulletin, 31(10), 1315-1326. doi: 10.1177/0146167205274892

López-Pérez, B., Fernández-Pinto, I., \& Abad, F.J. (2008). TECA. Test de Empatía Cognitiva y Afectiva. Madrid: TEA Ediciones, S.A.

McCullough, M. E., \& Hoyt, W. T. (2002). Transgression-related motivational dispositions: Personality substrates of forgiveness and their links to the Big Five. Personality and Social Psychology Bulletin, 28(11), 1556-1573. doi: $10.1177 / 014616702237583$ 
McCullough, M. E., Kilpatrick, S. D., Emmons, R. A., \& Larson, D. B. (2001). Is gratitude a moral affect?. Psychological Bulletin, 127(2), 249. doi: 0.1037/0033-2909.127.2.249

McCullough, M. E., Luna, L. R., Berry, J. W., Tabak, B. A., \& Bono, G. (2010). On the form and function of forgiving: Modeling the timeforgiveness relationships and testing the valuable relationships hypothesis. Emotion, 10(3), 358-376. doi: 10.1037/a0019349

McCullough, M. E., Rachal, K. C., Sandage, S. J., Worthington, E. L., Jr., Brown, S. W., \& Hight, T. L. (1998). Interpersonal forgiveness in close relationships II: Theoretical elaboration and measurement. Journal of Personality and Social Psychology, 75, 1586-1603. doi: 10.1037/00223514.75.6.1586

McCullough, M. E., Root, L. M., \& Cohen, A. D. (2006). Writing about the benefits of an interpersonal transgression facilitates forgiveness. Journal of Consulting and Clinical Psychology, 74, 887-897. doi:10.1037/0022006X.74.5.887

McCullough, M. E., Worthington Jr, E. L., \& Rachal, K. C. (1997). Interpersonal forgiving in close relationships. Journal of Personality and Social Psychology,73(2), 321. doi: 10.1037/0022-3514.73.2.321

Miguel-Tobal, J., Casado, M., Cano-Vindel, A. \& Spielberger, C. (2001). Inventario de Expresión de la Ira Estado-Rasgo STAXI-2. Madrid, España: TEA Ediciones.

Muñiz, J., Elosua, P., \& Hambleton, R. K. (2013). [International Test Commission Guidelines for test translation and adaptation:]. Psicothema, 25(2), 151-157. doi: 10.7334/psicothema2013.24

Muñiz, J., Hidalgo, A.M., García-Cueto, E., Martínez, R. y Moreno, R. (2005). Análisis de items. Madrid: La Muralla.

Muthén, L. K., \& Muthén, B. O. (1998-2011). Mplus user's guide, sixth ed. Los Angeles, CA: Muthén \& Muthén.

North, J. (1987). Wrongdoing and Forgiveness. Philosophy, 6, 449-508. doi: 10.1017/S003181910003905X

Paleari, F. G, Regalia, C., \& Fincham, F.D. (2009). Measuring offencespecific forgiveness in marriage: The Marital Offence-specific Forgiveness Scale (MOFS). Psychological Assessment, 21, 194-209. doi: $10.1037 / \mathrm{a} 0016068$

Rios, J., \& Wells, C. (2014). Validity evidence based on internal structure. Psicothema, 26(1), 108-116. doi: 10.7334/psicothema2013.260

Rye, M. S., Loiacono, D. M., Folck, C. D., Olszewski B. T., Heim, T. A. \& Madia, B. P. (2001). Evaluation of the psychometric properties of two forgiveness scales. Current Psychology, 20, 260-277. doi: 10.1007/s12144001-1011-6

Satorra, A., \& Bentler, P. M. (1988). Scaling corrections for statistics in covariance structure analysis (UCLA Statistics Series 2). Los Angeles: University of California at Los Angeles, Department of Psychology. Statmodel.com. (2016). Muthén \& Muthén, Mplus Home Page. [online] Available at: http://www.statmodel.com [Accessed 29 Nov. 2016].

Toussaint, L. L., Worthington, E. L., Jr., \& Williams, D. (2015). Forgiveness and health: Scientific evidence and theories relating forgiveness to better health. New York, NY: Springer.

Tsang, J., McCullough, M. E., \& Fincham, F. D. (2006). The longitudinal association between forgiveness and relationship closeness and commitment. Journal of Social and Clinical Psychology, 25, 448-472. doi: 10.1521/jscp.2006.25.4.448

Wade, N. G., Hoyt, W. T., Kidwell, J. E. M., \& Worthington, E. L., Jr. (2014). Meta-analysis of psychotherapeutic interventions to promote forgiveness. Journal of Consulting and Clinical Psychology, 82(1), 154-170. doi: $10.1037 / \mathrm{a} 0035268$

Wong, L. C., Chu, A. M., \& Chan, C. L. (2013). Measuring the Transgression-Related Interpersonal Motivations inventory in marital relationships: Forgiveness in the Chinese context (C-TRIM). Research on Social Work Practice, 1-8. doi: 10.1177/1049731513498622

Worthington, E. L., Jr. (Ed.). (2005). Handbook of forgiveness. New York, NY: Brunner-Routledge.

Worthington, E. L., Jr. (2006). Forgiveness and reconciliation: Theory and application. New York, NY: Brunner-Routledge.

Worthington, E. L., Jr., Lavelock, C., Witvliet, C. V. O., Rye, M. S., Tsang, J.-A., \& Toussaint, L. (2015). Measures of forgiveness: Self- report, physiological, chemical, and behavioral indicators. In Greg Boyle, Don Saklofske, \& Gerald Matthews (Eds.), Measures of personality and social psychological constructs (pp. 474-504). Waltham, MA: Elsevier/Academic. doi: 10.1016/B978-0-12-386915-9.00017-6

Yárnoz-Yaben, S., \& Comino, P. (2012). Un instrumento para la evaluación del perdón en el ámbito del divorcio y la separación. International Journal of Psychology and Psychological Therapy, 12(1), 49-58.

(Article received: 22-07-2016; revised: 13-11-2016; accepted: 13-12-2016) 